Article

\title{
Sustainability of Positive Psychological Status in the Workplace: The Influence of Organizational Psychological Ownership and Psychological Capital on Police Officers' Behavior
}

\author{
Yu-Shan Chen, Chun-Ming Lien, Wei-Yuan Lo * and Fuh-Shyong Tsay \\ Department of Business Administration, National Taipei University, New Taipei City 237, Taiwan; \\ yushan@gm.ntpu.edu.tw (Y.-S.C.); kevinlien988@gmail.com (C.-M.L.); tfs@dgpa.gov.tw (F.-S.T.) \\ * Correspondence: galas912@gmail.com
}

check for

updates

Citation: Chen, Y.-S.; Lien, C.-M.; Lo, W.-Y.; Tsay, F.-S. Sustainability of Positive Psychological Status in the Workplace: The Influence of

Organizational Psychological Ownership and Psychological Capital on Police Officers' Behavior. Sustainability 2021, 13, 2689. https://doi.org/10.3390/su13052689

Academic Editor: Christian Vandenberghe

Received: 5 February 2021

Accepted: 25 February 2021

Published: 2 March 2021

Publisher's Note: MDPI stays neutral with regard to jurisdictional claims in published maps and institutional affiliations.

Copyright: (c) 2021 by the authors. Licensee MDPI, Basel, Switzerland. This article is an open access article distributed under the terms and conditions of the Creative Commons Attribution (CC BY) license (https:/ / creativecommons.org/licenses/by/ $4.0 /)$.
Abstract: Drawing on the theory of conservation of resources (COR), the purpose of this study is to examine the mechanisms through which employee organizational citizenship behavior and job performance are affected by positive psychological status at work. Structural equation modeling was applied to analyze the data collected from 543 police officers in Northern Taiwan. The empirical results reveal that organizational psychological ownership positively associated with psychological capital, and psychological capital positively associated with both job performance and organizational citizenship behavior. Additionally, this study demonstrates that the relationship between organizational psychological ownership and job performance and organizational citizenship behavior are both fully mediated by psychological capital. Organizational psychological ownership and psychological capital are both positive psychological strengths to assist employees facing stressful work circumstances. The importance of examining the relationship between the components of organizational psychological ownership, psychological capital, job performance, and organizational citizenship behavior is pointed out due to the importance of organizations promoting the development of psychological resources to promote sustainable positive behavior and results in the workplace.

Keywords: organizational psychological ownership; psychological capital; organizational citizenship behavior; job performance; police officers

\section{Introduction}

Both in public and private organizational contexts, organizations are facing critical economic and managerial difficulties to survive in the market [1]. In order to maintain the competitive advantage and organizational growth, organizations have to utilize their strategic resources effectively, including the human resources [2]. The key to the sustainability of an organization is linked to the consideration of the unique and distinctive resources for organizations. Human resources, therefore, are the first and most important capital of the organization, and they are considered the key resource of an organization, cannot be easily imitated by competitors, and enable the generation of unique competitive advantage for organizational sustainability [3]. According to this argument, employees are assets of a skillful and committed workforce and are driven to create and maintain to achieve organizational goals. Employees have to be included in the organization structure through training and socialization [4]. Human resources can be seen as organizational resources that can leverage management strategies for sustainability [3]. Through human resource management, employees could reinforce the interpersonal/organizational relationship, motivate the workforce, and enhance performance and positive behavior [1]. However, in the organic working circumstance, employees inevitably experience job-related irrational demands and increase job dissatisfaction [5]. These negative experiences of employees may trigger them to disconnect or detach from their organizations and organizational members [6]. 
In addition, the relevant perceptions of employees have been proven to be significantly related to organizational resilience [1]. With the changes of organizational values, strategies, and structure in the work environment, employees will feel discomfort due to the degree of required adaptation [7]. These phenomena may result in detriments to both organizational and employee performance, organizational profit and effectiveness, and organizational sustainability [8,9]. Therefore, organizations have to strengthen the connection to their employees in order to sustain their organizational sustainability.

Sustainability means that what you do once will have a positive effect in the future [4]. Job performance is the accomplishment of a given task and expected results in terms of quantity and quality of the employee in the organization. It also relates to the act of reaching a goal within a job or organization [10]. Further, Robbins and Judge [11] defined organizational citizenship behavior as not part of an employee's formal job descriptions and requirements. Positive organizational behavior allows individuals and organizations to feel good at work, perform better, and finally generate competitive advantage for organizations [12]. Based on the abovementioned, sustainable organizational performance is dependent on a highly skilled and committed workforce [13]. The sustainability of human resources is being looked at to achieve sustainability outcomes [14]. Previous studies on sustainable development of the organization exhibit that the sustainability could be viewed beyond a wider socio-economic domain and investigate the psycho-social features of the working context that could create conditions to promote sustainable development $[15,16]$. This insight provides a wider perspective within the work and organizational psychology. With the crucial role of the organization, the intangible human capital could contribute to secure organizational performance and sustainability [1].

According to the theory of conservation of resources (COR) [17], the primary motivation of employees is to establish, protect, and cultivate the resources in order to protect and support the self. Through personal experience, employees recognize what they need to affirm the acquisition and ownership for survive. Pierce et al. [18] argued that the meaning of ownership is the fusing of the object with the self. In this context, psychological ownership refers to a situation in which the psychological ownership will effect and cause employees to regard an object as their possession and extension [18].

Differentiating from other constructs that describe the relationship between individual and organization, the core concept of psychological ownership is the sense of possession [18]. When an individual perceives possession of a target or a part of it, such as a sense of organizational psychological ownership, it becomes a part of the extending self [19]. The development and growth of the target can have a positive emotional effect on the individual, and will make them willing to take risks [18]. The sense of possession also affects personal attitudes and behaviors [18]. This target of ownership would result in providing a more complete explanation for sustained positive behaviors [20]. In the organizational context, psychological ownership can be a critical predictor of employees' attitudes, behaviors, and performance [18,21]. In contrast, if employees cannot feel that the organization is related to them, they cannot perceive the ownership and will be unwilling to make more sacrifices for the organization [18,22]. Therefore, when a psychological connection is established between the organization and the employee, the inside link will make the employee become much closer to the organization, generate more positive attitudes about the organization, and in turn, improve the individual's job performance [23].

Additionally, employees with high perception of organizational psychological ownership would consider that the organization is "mine" and is an extension of themselves [18]. This may lead employees to exhibit more responsibilities and to increase their job performance $[21,24,25]$. In contrast, when employees have a lack of enthusiasm or identification about their jobs or organizations, it may limit them in performing positive behaviors [26,27]. Van Dyne and Pierce [21] demonstrated that psychological ownership would affect an individual's attitude, motivation, and behavior. Pierce et al. [18] and Ko and Choi [28] also indicated that the organizational psychological ownership would have a significant effect on the willingness of civil servants to take risks or make sacrifices for their orga- 
nization, such as the military, police, and fire departments. Thus, employees with the experience of positive perceptions about their organization would lead to positive work behaviors $[17,29,30]$. However, scholars have paid scant attention on the organizational psychological ownership of the policing workforce and its positive effects, such as job performance and organizational citizenship behavior. Therefore, in this research, we aim at investigating the mechanisms through which organizational psychological ownership can increase an employee's job performance and organizational citizenship behavior.

In addition, psychological capital has received remarkable attention in the field of organizational behavior over decades. Positive psychology has had a notable influence on the strengths of the employee's health, well-being, and performance [31,32]. This is integrated in the psychology of sustainability and sustainable development both in the fields of the ecological and socioeconomic environment [33-35]. Psychological capital is a positive psychological state and a kind of positive psychological energy manifested by individuals [36,37], including self-efficacy, optimism, hope, and resiliency [38]. Previous studies have also demonstrated the relationship between employees' psychological capital and employees' job satisfaction, commitment, and performance [39-41]. Luthans et al. [42] indicated that organizations could enhance the long-term competitive advantage through strengthening the psychological capital ability of the members. Walumbwa et al. [43] also demonstrated that psychological capital will directly affect work attitudes and behaviors. Psychological capital is the antecedent of employees' work attitudes. Regardless of the type of organization, therefore, the responsibilities and behaviors of organization members are to create better performance. Based on the abovementioned, with positive psychological capital, employees would have positive attitudes and be more willing to achieve the organization's goals, increase the work performance [44], and enhance discretionary work behaviors $[45,46]$. Thus, employees' psychological capital is a critical factor to have a positive association with job performance and organizational citizenship behavior in the workplace $[17,47]$.

For individuals, organizational psychological ownership and psychological capital are both positive psychological constructs and would result in positive organizational behaviors in workplaces [48]. Therefore, with a meaningful and emotional connection to the organization, employees strongly believe that the work or the organization is "meaningful" [49-51]. Pierce et al. demonstrated that organizational psychological ownership can present a stronger motivation, a more positive attitude, and a higher perception of responsibility. They also indicated that organizational psychological ownership would increase confidence and positive attitudes of individuals, which may be related to the four elements of psychological capital [18]. Moreover, Pierce et al. [52] argued that ownership is a kind of presentation of the psychological state and is considered as the condition of "mine", which forms the relationship between an employee's attitude and behavior.

Previous studies suggest organizational psychological ownership could enhance job performance and organizational citizenship behavior, but do not explore clearly why organizational psychological ownership would enhance an individual's willingness to perform positive behavior. Additionally, employees with higher psychological capital would have greater confidence [53], and may stimulate organizational citizenship behavior [54]. Subsequent studies exploit psychological capital as the variable to predict organizational behaviors [55-57]. However, rare studies have identified psychological capital as a mediator between organizational psychological ownership and job performance and organizational citizenship behavior. We aim at increasing the explanation of the relationships of past findings by examining and testing the sample of police officers. Further, to anchor the theoretical arguments and to advance the literature, this study employs the theory of resource conservation and provides a much clearer picture of how organizational psychological ownership and psychological capital helps employees achieve higher job performance and organizational citizenship behavior. Lastly, drawing on previous literatures, we suggest psychological capital as a mediator explaining the relationships between organizational psychological ownership and job performance and organizational citizenship behavior. 
In sum, by exploring the paths, this study is aligned with the organizational psychology of sustainability and positive behavior, and advances our knowledge about the effects of the quality of the police at work.

\section{Literature Review and Hypothesis Development}

2.1. The Positive Influence of Organizational Psychological Ownership on Psychological Capital

Psychological ownership is a state in which an individual considers a particular object (intangible or tangible) as psychologically associated with, owned, and an extension of the owner [52]. Pierce et al. introduced psychological ownership as a cognitive-affective construct that is based on individuals' feelings for an object. They argued that psychological ownership is a kind of personal perception of ownership, which expresses that the object is "mine" and is an extension of oneself [18]. Psychological ownership consists of three elements, born with a sense of possession, the subject matter of possession, and the sense of ownership with a significant impact on individual attitudes and behaviors. It could meet three needs of human beings, including belonging, self-efficacy, and self-identity [23].

The roots of organizational psychological ownership are derived from three motives, namely having a place, efficiency and effect, and self-identification [52]. According to Pierce et al. [18], when employees have a higher perception of organizational psychological ownership, they will have more emotional connection with the organization, will consider the organization to be an extension of themselves, and will consider the success of the organization equaling to their success. Therefore, organizational psychological ownership can be viewed as a valid predictor of employee's work attitudes and behaviors [21].

Psychological capital is a positive psychological state, including self-efficacy, optimism, hope, and resilience [41,58]. Psychological capital refers to an individual's positive psychological state of development and is characterized by self-efficacy, optimism, hope, and resilience [38]. Goldsmith et al. [59] argued psychological capital could enhance individual productivity. According to Luthans et al., these four elements of psychological capital can effectively improve the individual's performance $[48,60]$. Theoretical and empirical studies have identified that features of these four elements of psychological capital have a comprehensive effect on each other, and the combining effect of predictive variable will be more significant [61,62].

Pierce et al. [18] indicated that organizational psychological ownership can present a stronger motivation, a more positive attitude, and a higher perception of responsibility. According to Coutu, when police officers have an emotional connection to the organization or work, they strongly believe they will recover from work [49]. Therefore, organizational psychological ownership can increase the resilience of psychological capital. Second, police officers with high organizational psychological ownership have a positive attitude towards specific things and have a more positive attribution to all things [18]. Thus, organizational psychological ownership can increase the optimism of psychological capital. Third, police officers with higher sense of organizational psychological ownership would have higher sense of responsibility and positive motivation to organization and work, and they would do their best to persist and to achieve their missions [18]. Hence, organizational psychological ownership can increase the hope of psychological capital. Fourth, police officers with higher perception of organizational psychological ownership would increase their self-confidence, because they realize that they have a greater control over things [18]. Therefore, organizational psychological ownership could increase the self-efficacy of psychological capital. Based on the aforementioned, police officers with higher perception of organizational psychological ownership would have a positive and proactive attitude to confront adversity $[63,64]$. Therefore, we postulate the following hypothesis:

Hypothesis 1 (H1). Organizational psychological ownership is positively associated with psychological capital. 


\subsection{The Positive Influence of Organizational Psychological Ownership and Psychological Capital on Job Performance}

Job performance is regarded as an important outcome variable of organizational performance and organizational behavior [11,65-67]. Positive work outcomes, such as motivation, satisfaction, and performance, will be presented when "positive psychological states" are exhibited [68,69]. These positive psychological states include meaningfulness of the work and experiencing responsibility for the work [70,71]. Organizational psychological ownership has been identified as a motivation of employees to improve job performance [21]. Previous studies indicate that psychological ownership relates positively to job attitudes and work behaviors, such as job performance [72]. Md-Sidin et al. [73] also pointed out that organizational psychological ownership has positively significant relations to job commitment, job satisfaction, and performance. Hence, hypothesis 2 of this study is as follows:

Hypothesis 2 (H2). Organizational psychological ownership is positively associated with job performance.

Employees with psychological capital are efficacious, optimistic, hopeful, and resilient, and filled with positive psychological resources [38]. Psychological capital is a critical resource that is utilized to organizational competitive advantage. Based on the conservation of resources theory, proactivity can maintain an individual's motivation and performance and can be used to help individuals face multiple challenges at work and enhance job performance $[35,74,75]$. Employees with higher psychological capital tend to have optimism, hope, and self-efficacy, exhibit resilience to persist in the face of challenges, and accomplish their own success [54].

The positive relationship between psychological capital and job performance is well established in the literature [76-78]. According to Bandura [79], employees with higher self-efficacy may have better performance, because they are more confident of taking on the challenge and demonstrating confidence in achieving their goals [80,81]. Luthans et al. [48] also indicated that psychological capital is positively related to job performance. Gooty et al. [77] indicated that employees with psychological capital exhibit better in-role performance. Avey et al. [78] also demonstrated the positive relationship between psychological capital and job performance. Based on the abovementioned, psychological capital has a positive relationship with job performance [48]. This current research employs the viewpoint of Luthans et al. [48] in defining psychological capital as a police officer's positive psychological state, enabling the individual to have sufficient psychological resources, and stimulating the individual towards his/her goal. Thus, police officers with higher psychological capital are more likely to have better job performance [70]. Hypothesis 3 of this study is as follows:

Hypothesis 3 (H3). Psychological capital is positively associated with job performance.

2.3. The Positive Influence of Organizational Psychological Ownership and Psychological Capital on Organizational Citizenship Behavior

Konovsky and Pugh [82] argued organizational citizenship behavior is when a member of the organization undertakes responsibilities beyond the requirement of the job and does not receive rewards from the organization [83,84]. Organ [85] indicated organizational citizenship behavior means organizational members do not require rewards but are still willing to help their colleagues and the organization's development [86]. This study refers to the definition of Williams and Anderson [87], who stated organizational citizenship behavior could benefit the organization and be divided into intra-role behavior, organizational interest behavior, and interpersonal altruism behavior [88,89].

According to previous studies, organizational psychological ownership is associated with related individual's behavior [90]. Van Dyne and Pierce [21] had empirically identified a positive relationship between organizational psychological ownership, job performance, 
and organizational citizenship behavior. They indicated that employees with organizational psychological ownership have three main characteristics, which enable employees to express positive feelings and attitudes about tangible and intangible goals, which are followed by enhanced self-concept and making the members of the organization regard tangible and intangible goals as their own extension, and finally, a sense of responsibility, which encourages the members of the organization to assume the responsibility of protecting or defending their ownership [21]. Therefore, employees with organizational psychological ownership will regard themselves as the owner of the organization, thereby creating a psychological contract that strengthens the relationship between employees and the organization, so that employees are willing to go beyond their original roles and responsibilities, and are more willing to participate in the organization and organizational decision making [21]. Vande Walle et al. [91] also examined the relationships between psychological ownership and commitment and satisfaction to the cooperative and perceptions of extra-role behavior. Organizational psychological ownership results in behaviors that promote the belongingness to the organization and the achievement of organizational goals [92]. Hence, employees practice initiatives to improve the operation of their organization and present an organizational citizenship behavior when they regard the organization as an extension of themselves. Based on relevant researches, hypothesis 4 is as follows:

Hypothesis 4 (H4). Organizational psychological ownership is positively associated with organizational citizenship behavior.

Based on the conservation of resources theory, individuals with high psychological capital can invest to acquire other resources and increase the accumulation of their own resources into their work $[17,93]$. Prior studies suggest employees with high psychological capital should have high organizational citizenship behavior [61,74]. To regain the accumulation of resources, employees with high psychological capital continue to invest positive resources in their work, thus exhibiting excellent organizational citizenship behavior [94]. According to relevant studies, positive attitudes, such as psychological capital, will positively associate with organizational citizenship behavior [71]. Therefore, hypothesis 5 is presented as follows:

Hypothesis 5 (H5). Psychological capital is positively associated with organizational citizenship behavior.

2.4. The Mediating Effect of Psychological Capital on Organizational Psychological Ownership, Job Performance, and Organizational Citizenship Behavior

Organizational psychological ownership and psychological capital are both positive psychological constructs and result in positive organizational behavior, such as employees' performance, attitudes, and behaviors in the workplace [95]. Pierce et al. indicated that organizational psychological ownership could generate a stronger motivation, a more positive attitude, and a higher perception of responsibility [18]. Moreover, psychological capital is a kind of positive psychological energy manifested by individuals [96]. Luthans et al. [48] indicated that psychological capital presents individual motivation that would accrue through positive psychological states. Positive psychological state could stimulate individual's resilience [74], hope [97], and optimism [98]. Additionally, Pierce et al. [18] had demonstrated organizational psychological ownership would have positive correlation with psychological capital. Based on the abovementioned, this current study alleges when employees perceive the sense of organizational psychological ownership, their psychological capital is improved, which in turn motivates and facilitates their job performance and organizational citizenship behavior. Hypotheses 6 and 7 of this study are thus stated as follows:

Hypothesis 6 (H6). Psychological capital has a mediating effect between organizational psychological ownership and job performance. 
Hypothesis 7 (H7). Psychological capital has a mediating effect between organizational psychological ownership and organizational citizenship behavior.

\section{Methodology}

\subsection{Sample and Data Collection}

This study applied the questionnaire survey to verify the hypotheses and research framework. Respondents were informed that the survey was anonymous and were assured of the confidentiality. We followed the standard back-translation procedure to translate all items into Chinese [99]. In addition, we scrutinized the normal distribution test. The Kolmogorov-Smirnov value was $0.078(p>0.05)$, the kurtosis value was 0.357 $(<10)$, and the skewness value was $-0.257(<|3|)$ [100]. Hence, the data should be normal distribution in the statistics. Afterwards, we used statistical software SPSS 20 and AMOS 18 for data analysis. With the assistance of the personnel director of the police department, we sent the questionnaires to the director of the police station, and the director distributed the questionnaires to the police officers of the patrol team. After filling out the questionnaire, the police officer put and sealed it in the envelope. Then the director sent the questionnaires back to the personnel director of the police department. Among the total of 550 copies distributed, 543 valid questionnaires were collected, resulting in a response rate of $98.7 \%$. Most of the respondents were male $(82.7 \%)$, and the largest proportion of respondents were between 41 to 50 years old (36.5\%). Slightly less than half of the respondents had less than 10 years of work experience (47.6\%). Additional details of the demographic profiles are provided in Table 1.

Table 1. Demographic Profile.

\begin{tabular}{cccc}
\hline Variables & Category & No. of Samples & Percentage (\%) \\
\hline Gender & Male & 449 & 82.7 \\
& Female & 94 & 17.3 \\
Age & 21-30 years old & 135 & 24.9 \\
& 31-40 years old & 162 & 29.8 \\
41-50 years old & 198 & 36.5 \\
Education & 51-60 years old & 46 & 8.5 \\
& Police College & 276 & 50.8 \\
& Grade IV Examination Class & 118 & 21.7 \\
& Grade III Examination Class & 34 & 6.3 \\
& Police University Two-year & 35 & 6.4 \\
& academic system & & \\
& Police University Four-year & 71 & 13.1 \\
Marital Status & academic system & 9 & 1.7 \\
& Master degree or above & 332 & 61.1 \\
& Married & 211 & 38.7 \\
& Unmarried & 283 & 52.1 \\
& Police Rank 2 & 111 & 20.4 \\
& Police Rank 1 & 63 & 11.6 \\
& Inspector & 86 & 15.9 \\
& Senior Inspector & 123 & 22.7 \\
& 5 years or less & 135 & 24.9 \\
& 6-10 years & 30 & 5.5 \\
& 11-15 years & 34 & 6.3 \\
& 16-20 years & 117 & 19.2 \\
\hline 21-25 years & 104 &
\end{tabular}

\subsection{Measures}

Organizational Psychological Ownership We adopted a seven-item and self-report measurement developed and validated by Van Dyne and Pierce [21]. The response format of organizational psychological ownership was a seven-point Likert-type scale $(1$, totally 
disagree, to 7, totally agree). Sample item was "I have a high sense of identity with the present police unit". The scale's reliability Cronbach's alpha was 0.90 in this research.

Psychological capital Psychological capital consists of four positive dimensions, resilience, optimism, hope, and self-efficacy. We adopted a self-report measurement of psychological capital developed and validated by Luthans et al. [48] to assess psychological capital. The response format of psychological capital was a seven-point Likert-type scale (1, totally disagree, to 7 , totally agree). The measure combines the four dimensions of psychological capital. Sample item was "no matter what kind of work I do, I always think positively of it". The scale's reliability Cronbach's alpha was 0.95 in this research.

Job performance Job performance consists of three dimensions, work efficiency, work efficacy, and work quality. We assessed this variable using the scale developed and validated by Schermerhorn et al. [101]. Job performance could be assessed by supervisors, subordinates (self), and peers [102]. Considering the characteristics of police and avoiding the bias of supervisors, the response format of job performance was a sevenpoint Likert-type scale (1, totally disagree, to 7 , totally agree) and peer-rated performance measure appraised by their colleagues. Sample item was "my colleague will complete his/her work in accordance with the standard operating procedures". The scale's reliability Cronbach's alpha was 0.87 in this research.

Organizational Citizenship Behavior Based on a study of Williams and Anderson [87], there are three dimensions of measuring organizational citizenship behavior, in-role behavior, organizational citizenship behavior of individuals, and the organizational citizenship behavior of organizations. The response format of organizational citizenship behavior was a seven-point Likert-type scale ( 1 , totally disagree, to 7 , totally agree). The measure combines the three dimensions of organizational citizenship behavior. Sample item was "I shall achieve the performance and standards set by my unit." The scale's reliability Cronbach's alpha was 0.93 in this research.

\section{Results}

\subsection{Reliability and Validity}

Table 2 presents the means, standard deviations, composite reliability (CR), Cronbach's $\alpha$, the average variance extracted (AVE), and correlation coefficient among the variables of this current study. All of the correlation coefficients between variables were medium correlations. The composite reliability values ranged from 0.76 to 0.91 in this study and were all above the minimum values of 0.70 as recommended [103]. The AVE of each construct exceeded the recommended value of 0.50 [103]. According to Hair et al. [104], the estimated inter-correlations among the variables were less than the square roots of AVE for each variable, which supported the discriminant validity of the scales.

Table 2. Descriptive statistics and correlation coefficients.

\begin{tabular}{ccccccccc}
\hline Variable & Mean & $\begin{array}{c}\text { Standard } \\
\text { Deviation }\end{array}$ & $\begin{array}{c}\text { Composite } \\
\text { Reliability }\end{array}$ & Cronbach's $\alpha$ & $\begin{array}{c}\text { Average Variance } \\
\text { Extracted }\end{array}$ & $\mathbf{1}$ & $\mathbf{2}$ & $\mathbf{3}$ \\
\hline $\begin{array}{c}\text { 1. Organizational } \\
\text { Psychological } \\
\quad \text { Ownership }\end{array}$ & 4.982 & 0.045 & 0.91 & 0.90 & 0.55 & $\mathbf{0 . 7 4 2}$ & \\
$\begin{array}{c}\text { 2. Psychological } \\
\quad \text { Capital }\end{array}$ & 4.919 & 0.035 & 0.91 & 0.95 & 0.71 & $0.672^{* *}$ & $\mathbf{0 . 8 4 3}$ \\
$\begin{array}{c}\text { 3. Job Performance } \\
\text { 4. Organizational } \\
\quad \text { Citizenship }\end{array}$ & 5.012 & 0.036 & 0.76 & 0.87 & 0.51 & $0.446^{* *}$ & $0.687^{* *}$ & $\mathbf{0 . 7 1 4}$ \\
$\quad$ Behavior & 5.505 & 0.032 & 0.85 & 0.93 & 0.66 & $0.486^{* *}$ & $0.657^{* *}$ & $0.700^{* *}$ \\
\hline
\end{tabular}

Notes: $N=543,{ }^{* *} p<0.01$. The bold diagonal line shows the square root of AVE.

\subsection{Model-Data Fit}

We performed confirmatory factor analyses (CFA) to evaluate the fit of our data to this measurement model. All the model fit indices exceeded the recommended value of 
0.90 [105]. The RMSEA was 0.056 , which was an acceptable fit $[105,106]$. Thus, the goodnessof-fit indexes for the measurement model were acceptable $(\mathrm{CMIN} / \mathrm{df}=2.69$, RMSEA $=0.056$, $\mathrm{CFI}=0.97, \mathrm{TLI}=0.96, \mathrm{IFI}=0.97, \mathrm{GFI}=0.94$ ).

\subsection{Structural Model}

The results of the model path analysis conducted in this study are presented in Figure 1. The standardized path coefficient (SPC) of the direct effect of organizational psychological ownership on psychological capital was statistically significant $(\mathrm{SPC}=0.63, p<0.001$ ), whereas the direct effect of organizational psychological ownership on job performance and organizational citizenship behavior were not statistically significant, respectively (SPC $=-0.06$ and 0.02 , respectively). Hence, hypotheses 1 was supported, but hypotheses 2 and 4 were not supported.

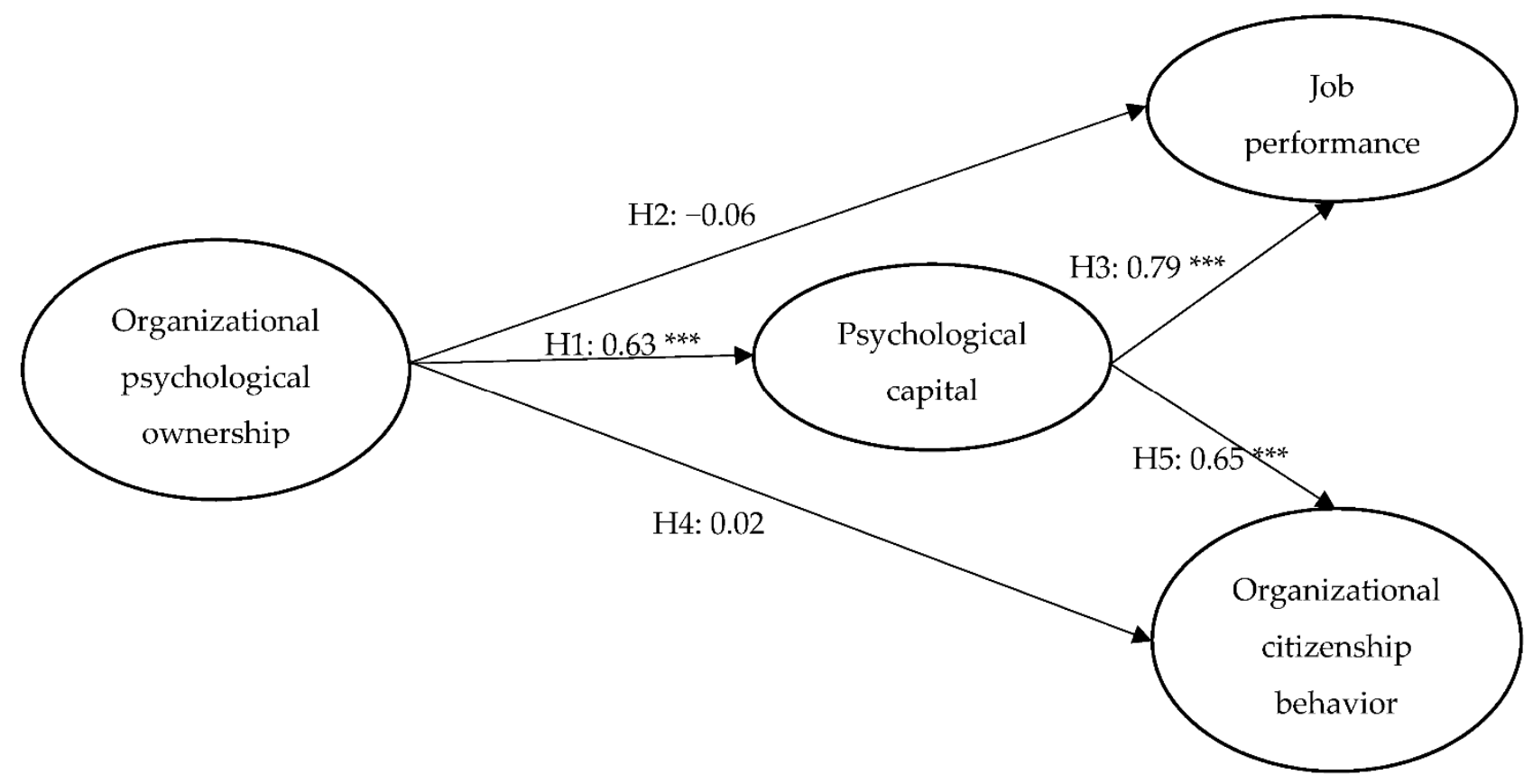

Figure 1. The path coefficients of direct effects.

\subsection{Mediating Effect}

The direct effects of psychological capital on job performance and organizational citizenship behavior were statistically significant (SPC $=0.79$ and $0.65, p<0.001$, respectively); therefore, hypotheses 3 and 5 were both supported. As exhibited in Figure 2, the standardized path coefficients (SPC) of the indirect effects were statistically significant (SPC $=0.79$ and $0.64, p<0.001$, respectively). In addition, the $\mathrm{Z}$ values of $\mathrm{H} 6$ and $\mathrm{H} 7$ were 2.09 and 3.87 , respectively, and the $Z$ values were all above the threshold value of 1.96 . Since these indirect effects were significant, psychological capital had a fully mediating effect between organizational psychological ownership, job performance, and organizational citizenship behavior. Therefore, hypotheses 6 and 7 were both supported, as presented in Table 3 . 


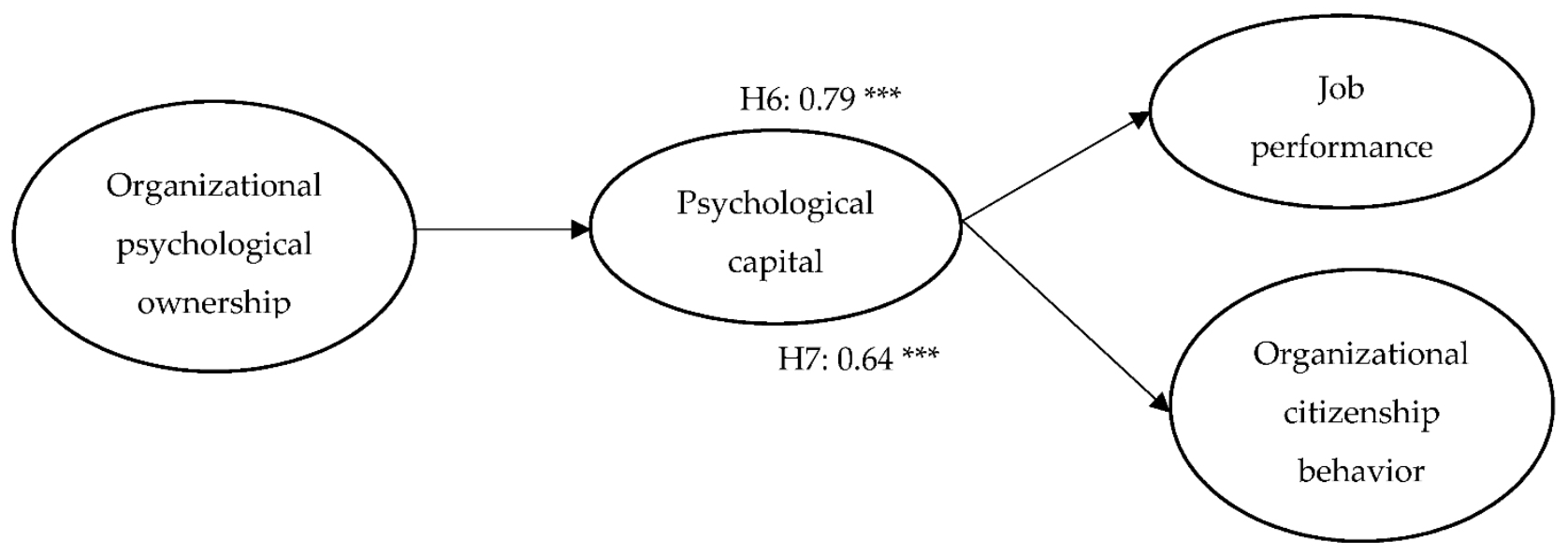

Figure 2. The path coefficients of indirect effects.

Table 3. Results of path analysis.

\begin{tabular}{|c|c|c|c|}
\hline Research Hypothesis & Coefficient & $t$ Value & Results \\
\hline $\begin{array}{c}\text { H1: Organizational Psychological } \\
\text { Ownership is positively associated with } \\
\text { Psychological Capital. }\end{array}$ & $0.63^{* * *}$ & 13.26 & Support \\
\hline $\begin{array}{c}\text { H2: Organizational Psychological } \\
\text { Ownership is positively associated with } \\
\text { Job Performance. }\end{array}$ & -0.06 & -1.35 & Not support \\
\hline $\begin{array}{l}\text { H3: Psychological Capital is positively } \\
\text { associated with Job Performance. } \\
\text { H4: Organizational Psychological }\end{array}$ & $0.79^{* * *}$ & 11.60 & support \\
\hline $\begin{array}{l}\text { Ownership is positively associated with } \\
\text { Organizational Citizenship Behavior. }\end{array}$ & 0.02 & 0.39 & Not Support \\
\hline $\begin{array}{l}\text { H5: Psychological Capital is positively } \\
\text { associated with Organizational } \\
\text { Citizenship Behavior. }\end{array}$ & $0.65^{* * *}$ & 11.43 & Support \\
\hline Mediation effect hypothesis & \multicolumn{2}{|c|}{ Sobel $\mathrm{Z}$ value } & Results \\
\hline $\begin{array}{l}\text { H6: Psychological Capital has a mediating } \\
\text { effect between Organizational } \\
\text { Psychological Ownership and } \\
\text { Job Performance. }\end{array}$ & \multicolumn{2}{|c|}{$2.09 *$} & Support \\
\hline $\begin{array}{l}\text { H7: Psychological Capital has a mediating } \\
\text { effect between Organizational } \\
\text { Psychological ownership and } \\
\text { Citizenship Behavior. }\end{array}$ & \multicolumn{2}{|c|}{$3.87^{* *}$} & Support \\
\hline
\end{tabular}

\section{Discussion}

For organizations, non-material effects, such as psychological effects, may be better than material effects, such as salary compensation, to retain talents. It is because material effects can be imitated easily, and even forms a vicious circle [97]. Positive job-related identity can make employees proud of being a part of their groups, and further facilitate their positive behaviors [28]. Therefore, organizational psychological ownership and psychological capital will be the critical factors to organizational sustainability and retaining talents [97].

In the working context, Dutton et al. emphasized the importance of positive job-related virtuous attributes [107]. As a kind of virtual ownership, organizational psychological ownership can not only influence the attitude, but also facilitate the positive behaviors of employees [108]. Based on the conservation of resources theory [17], the empirical results of this study reveal an incremental contribution by verifying effects of organizational 
psychological ownership on psychological capital, job performance, and organizational citizenship behavior. First, previous studies suggest organizational psychological ownership enhances individuals to have a high confidence and a highly positive attitude that may be related to psychological capital [52]. Based on the result of the current study, the higher the perception of organizational psychological ownership is, the more abundant the psychological capital is.

Second, an employee's positive psychological state characterized by efficacy, optimism, hope, and resilience [28]. This research also investigated the roles of psychological capital in predicting job performance and organizational citizenship behavior. Consistent with relevant researches of psychological capital [58,62], the results of this study reveal that the psychological capital of police officers is related to their job performance and organizational citizenship behavior.

In addition, employees experience either negative or challenging incidents in the workplace and damage their psychological resources. Past studies have examined the mechanisms of mediating effect of psychological capital, and illustrated social support is an important situational factor to influence the psychological capital, and in turn, to achieve job performance $[28,109,110]$. It seems integral for organizations to replenish the psychological resources of employees and keep them engaged at work in order to achieve organizational goals and sustainability. We suggested that organizational psychological ownership could help employees build positive psychological resources so that they can better handle positive behaviors to accomplish their goals. Our results demonstrated that psychological capital had fully mediating effects between organizational psychological ownership and job performance and organizational citizenship behavior. The current research used an integrated view to examine the effect of positive psychological states on relevant positive outcomes. In accordance with relevant postulations, these results correspond to the previous research outcomes [111]. Organizational psychological ownership enhances individuals' psychological capital, and in turn, positively affects their job performance and organizational citizenship behavior.

\subsection{Managerial Implications}

Sustainable management is a holistic approach within an organization and must consider the impact on externalities of society, economy, and the environment [112]. This study identified that psychological capital fully mediated the relationship between organizational psychological ownership, job performance, and organizational citizenship behavior. Employees' psychological capital is a useful personal resource that managers can leverage to integrate personal resources in order to enhance job performance and organizational citizenship behavior of police officers, even in an unfavorable circumstance or under stresses. Therefore, we should take the value of recruiting and retaining police officers who have high levels of psychological capital.

Second, according to previous studies, psychological capital had a positive relationship to job performance [113]. Luthans et al. [48] argued that the investment in psychological capital may yield more substantial feedback then the other traditional forms of capital investment. Psychological capital of employees can be developed through training initiatives [113]. As a result, to spur police officers' psychological capital, police departments have to offer relevant staff assistant initiatives to enhance the psychological capital of police officers.

Third, organizational psychological ownership is a key catalyst to influence the psychological capital of police officers. Supervisors should pay attention to enhance police officers' perception of belonging, efficacy, and self-identification in order to maintain a longterm stable organizational psychological ownership, and to promote the development of psychological capital, job performance, and organizational citizenship behavior. Van Dyne and Pierce [21] suggested that managers may want to pay attention to employees' feelings when employees' attitudes were critical to affect their work effectiveness. Thus, police departments must strive to enhance police officers' sense of organizational psychological 
ownership for the organization through improving the supervisor-subordinate relationship in the police internal leadership, and to enhance the cohesiveness of the organization. Further, police departments may empower police officers' autonomy and allow them to participate in decision making processes.

Fourth, the research has shown that police officers with organizational psychological ownership and psychological capital achieve better job performance and organizational citizenship behavior in a challenging work environment. Managers can influence the job demands and resources of police officers to mobilize their psychological resources through training initiatives. Thereafter, managers could assist police officers to build a clearer picture of using their strengths at work, and in turn, could improve their personal psychological resources, performance, and organizational citizenship behavior.

\subsection{Limitations and Future Research}

Several limitations should be recognized for future research. First, the sample of this study was collected from the police department, and the results could be affected because of the characteristics of the job of the police. Future studies can extend the framework of this study to verify the results to different occupations, industries, and countries. Second, this study used the cross-sectional data that can only explain the research at a particular moment. Future study should use longitudinal data to examine the relevant results. Third, human resource management had taken psychological capital as a powerful predictor of several positive outcomes. Thus, relevant practices should be met to achieve such capacities by focusing on what would improve or enhance psychological capital. The residual variance component of organizational psychological ownership, job performance, organizational citizenship behavior, and psychological capital indicated there might be other predictors, such as the supervisor-subordinate relationship or leadership, which can explain part of the variance in the relevant research. Therefore, further research could take other psychological variables or control variables that can explain the research model. Fourth, there are some aspects of organizational psychological ownership that may affect other important work outcomes through psychological capital in different work environments. Future research can extend the findings of this current study to verify the relationship with other relevant outcome variables. Fifth, the current study was in an Eastern-based work environment. Results may be diverse and varied due to different cultural impacts. Future research can take foci on cross-cultural comparisons to verify these results.

\section{Conclusions}

This study offers a valuable insight to extend research by investigating the unexplored, integrated effects of organizational psychological ownership, job performance, organizational citizenship behavior, and psychological capital. Using the theory of resource conservation as a conceptual framework, a specific recommendation from this research highlights a deeper understanding of the "black box" that links organizational psychological ownership to job performance and organizational citizenship behavior through psychological capital. According to the results of this research, positive psychology has presented in related fields such as positive organizational behavior. Employees with positive psychology may not feel frustrated despite being exposed to stressful situations and high working demands. It is because they may possess positive psychological characteristics that help them to recover immediately. Organizational psychological ownership and psychological capital, therefore, are both positive states to assist employees to face the challenging work environment or stressful circumstances.

Author Contributions: Conceptualization, Y.-S.C.; methodology, Y.-S.C. and W.-Y.L.; software, C.M.L. and F.-S.T.; validation, Y.-S.C., C.-M.L. and W.-Y.L.; formal analysis, W.-Y.L. and F.-S.T.; investigation, Y.-S.C. and F.-S.T.; resources, Y.-S.C.; data curation, Y.-S.C. and F.-S.T.; writing-original draft preparation, C.-M.L. and W.-Y.L. All authors have read and agreed to the published version of the manuscript. 
Funding: This research received no external funding.

Institutional Review Board Statement: Not applicable.

Informed Consent Statement: Not applicable.

Data Availability Statement: The data used to support the findings of this study are available from the corresponding author by request.

Conflicts of Interest: The authors declare no conflict of interest.

\section{References}

1. Manuti, A.; Giancaspro, M.L.; Molino, M.; Ingusci, E.; Russo, V.; Signore, F.; Zito, M.; Cortese, C.G. "Everything Will Be Fine": A Study on the Relationship between Employees' Perception of Sustainable HRM Practices and Positive Organizational Behavior during COVID19. Sustainability 2020, 12, 10216. [CrossRef]

2. Barney, J.B. Firm resources and sustained competitive advantage. J. Manag. 1991, 17, 99-120. [CrossRef]

3. Yong, J.Y.; Yusliza, M.Y.; Ramayah, T.; Jabbour, C.J.C.; Sehnem, S.; Venkatesh, M. Pathways towards sustainability in manufacturing organizations: Empirical evidence on the role of green human resource management. Bus Strat. Environ. 2019, 29, $212-228$. [CrossRef]

4. Manzoor, F.; Wei, L.; Bányai, T.; Nurunnabi, M.; Subhan, Q.A. An Examination of Sustainable HRM Practices on Job Performance: An Application of Training as a Moderator. Sustainability 2019, 11, 2263. [CrossRef]

5. Weiss, H.M.; Cropanzano, R. Affective events theory: A theoretical discussion of the structure, causes and consequences of affective experiences at work. In Research in Organization Behavior; Staw, B.M., Cummings, L.L., Eds.; JAI Press: Greenwich, CT, USA, 1996; pp. 1-74.

6. McCann, L. Disconnected amid the networks and chains: Employee detachment from company and union after offshoring. Br. J. Ind. Relat. 2013, 52, 23-260. [CrossRef]

7. Rafferty, A.E.; Jimmieson, N.L. Subjective Perceptions of Organizational Change and Employee Resistance to Change: Direct and Mediated Relationships with Employee Well-being. Br. J. Manag. 2016, 28, 248-264. [CrossRef]

8. Johnson, J.W. Toward a better understanding of the relationship between personality and individual job performance. In Personality and Work; Barrick, M., Ryan, A.M., Eds.; Jossey-Bass: San Francisco, CA, USA, 2003; pp. 83-120.

9. Motowildo, S.J.; Borman, W.C.; Schmit, M.J. A theory of individual differences in task and contextual performance. Hum. Perform. 1997, 10, 71-83. [CrossRef]

10. Campbell, J.P. Modeling the Performance Prediction Problem in Industrial and Organizational Psychology. In Handbook of Industrial and Organizational Psychology; Dunnette, M.D., Hough, L.M., Eds.; Consulting Psychologists Press: Palo Alto, CA, USA, 1990; pp. 687-732.

11. Robbins, S.P.; Judge, T.A. Essentials of Organizational Behavior, 12th ed.; Pearson Education: Upper Saddle River, NJ, USA, 2014.

12. Cameron, K.S.; Spreitzer, G.M. The Oxford Handbook of Positive Organizational Scholarship; Oxford University Press: Oxford, UK, 2012.

13. Ehnert, I.; Parsa, S.; Roper, I.; Wagner, M.; Muller-Camen, M. Reporting on sustainability and HRM: A comparative study of sustainability reporting practices by the world's largest companies. Int. J. Hum. Resour. Manag. 2016, 27, 88-108. [CrossRef]

14. Chillakuri, B.; Vanka, S. Examining the effects of workplace well-being and high-performance work systems on health harm: A Sustainable HRM perspective. Soc. Bus. Rev. 2020, 16, 71-93. [CrossRef]

15. Arcangeli, G.; Giorgi, G.; Mucci, N.; Bernaud, J.L.; di Fabio, A. Emerging and Re-Emerging Organizational Features, Work Transitions and Occupational Risk Factors: The Good, the Bad, the Right: An Interdisciplinary Perspective. Front. Psychol. 2017,8 , 1534.

16. Di Fabio, A.; Rosen, M.A. Opening the black box of psychological processes in the science of sustainable development: A new frontier. Eur. J. Sustain. Dev. Res. 2018, 2, 1-5. [CrossRef]

17. Hobfoll, S.E. Social and psychological resources and adaptation. Rev. Gen. Psychol. 2002, 6, 307-324. [CrossRef]

18. Pierce, J.L.; Kostova, T.; Dirks, K.T. Toward a theory of psychological ownership in organizations. Acad. Manag. Rev. 2001, 26, 298-310. [CrossRef]

19. Cocieru, O.C.; Lyle, M.C.B.; Hindman, L.C.; McDonald, M.A. The 'dark side' of psychological ownership during times of change. J. Chang. Manag. 2019, 19, 266-282. [CrossRef]

20. Gardner, D.G.; Pierce, J.L.; Peng, H. Social exchange and psychological ownership as complementary pathways from psychological contract fulfillment to organizational citizenship behaviors. Pers. Rev. 2020. [CrossRef]

21. Van Dyne, L.; Pierce, J.L. Psychological Ownership and Feelings of Possession: Three Field Studies Predicting Employee Attitudes and Organizational Citizenship Behavior. J. Organ. Behav. 2004, 25, 439-459. [CrossRef]

22. Pratt, M.G.; Dutton, J.E. Owning up or opting out: The role of emotions and identities in issue ownership. In Emotions in the Workplace: Research, Theory, and Practice; Ashkanasy, N.M., Härtel, C.E., Zerbe, W.J., Eds.; Quorum Books/Greenwood Publishing Group: Santa Barbara, CA, USA, 2000; pp. 104-129.

23. Mustafa, M.; Ramos, H.M.; Man, T.W.Y. Linking psychological ownership to employee extra-role behaviors in small overseas Chinese family businesses: Does family status matter? J. Entrep. Emerg. Econ. 2015, 7, 129-147.

24. Barrick, M.R.; Parks-Leduc, L. Selection for Fit. Annu. Rev. Organ. Psychol. Organ. Behav. 2019, 6, 171-193. [CrossRef] 
25. Earl, J.; Iskandar, F.; Elizondo, F. Take a Job, Any Job: Exploring the Importance of Matched Interests to Career Paths and Work Satisfaction. J. Employ. Couns. 2019, 56, 33-45. [CrossRef]

26. Quinn, R.W.; Spreitzer, G.M.; Lam, C.F. Building a sustainable model of human energy in organizations: Exploring the critical role of resources. Acad. Manag. Ann. 2012, 6, 337-396. [CrossRef]

27. De Clercq, D.; Haq, I.; Azeem, M. Dissatisfied employees, diminished helping: Using psychological capital to buffer the damaging effects of job dissatisfaction on helping behaviours. J. Manag. Organ. 2019, 1-15. [CrossRef]

28. Ko, S.H.; Choi, Y.J. Compassion and Job Performance: Dual-Paths through Positive Work-Related Identity, Collective Self Esteem, and Positive Psychological Capital. Sustainability 2019, 11, 6766. [CrossRef]

29. Pan, X.F.; Qin, Q.; Gao, F. Psychological ownership, organization-based self-esteem and positive organizational behaviors. Chin. Manag. Stud. 2014, 8, 127-148. [CrossRef]

30. Van Gelderen, B.R.; Konijn, E.A.; Bakker, A.B. Emotional labor among police officers: A diary study relating strain, emotional labor, and service performance. Int. J. Hum. Resour. Manag. 2017, 28, 852-879. [CrossRef]

31. Schaufeli, W.; Bakker, A.B. Job demands, job resources, and their relationship with burnout and engagement: A multi-sample study. J. Organ. Behav. 2004, 25, 293-315. [CrossRef]

32. Di Fabio, A. Positive Relational Management for Healthy Organizations: Psychometric Properties of a New Scale for Prevention for Workers. Front. Psychol. 2016, 7, 1523. [CrossRef]

33. Di Fabio, A. The Psychology of Sustainability and Sustainable Development for Well-Being in Organizations. Front. Psychol. 2017, 8, 1534. [CrossRef] [PubMed]

34. Di Fabio, A.; Tsuda, A. The Psychology of Harmony and Harmonization: Advancing the Perspectives for the Psychology of Sustainability and Sustainable Development. Sustainability 2018, 10, 4726. [CrossRef]

35. López-Núñez, M.I.; Rubio-Valdehita, S.; Diaz-Ramiro, E.M.; Aparicio-García, M.E. Psychological Capital, Workload, and Burnout: What's New? The Impact of Personal Accomplishment to Promote Sustainable Working Conditions. Sustainability 2020, $12,8124$. [CrossRef]

36. Baron, R.A.; Franklin, R.J.; Hmieleski, K.M. Why entrepreneurs often experience low, not high, levels of stress: The joint effects of selection and psychological capital. J. Manag. 2016, 42, 742-768. [CrossRef]

37. Olaniyan, O.S.; Hystad, S.W. Employees' psychological capital, job satisfaction, insecurity, and intentions to quit: The direct and indirect effects of authentic leadership. J. Work Organ. Psychol. 2016, 32, 163-171. [CrossRef]

38. Luthans, F.; Avolio, B.J.; Youssef, C.M. Psychological Capital: Developing the Human Competitive Edge; Oxford University Press: New York, NY, USA, 2006.

39. Youssef-Morgan, C.M.; Luthans, F. Psychological Capital and Well-being. Stress Health 2015, 31, 180-188. [CrossRef] [PubMed]

40. Kong, F.; Tsai, C.H.; Tsai, F.S.; Huang, W.; de la Cruz, S. Psychological Capital Research: A Meta-Analysis and Implications for Management Sustainability. Sustainability 2018, 10, 3457. [CrossRef]

41. Azanza, G.; Gorgievski, M.J.; Moriano, J.A.; Molero, F. Influencing salespeople's work outcomes through authentic leadership. Leadersh. Organ. Dev. J. 2018, 39, 926-944. [CrossRef]

42. Luthans, F.; Youssef, C.M.; Avolio, B.J. Psychological Capital and Beyond; Oxford University Press: New York, NY, USA, 2015.

43. Walumbwa, F.O.; Luthans, F.; Avey, J.B.; Oke, A. Authentically leading groups: The mediating role of collective psychological capital and trust. J. Organ. Behav. 2011, 32, 4-24. [CrossRef]

44. Lu, L.; Liu, L.; Sui, G.; Wang, L. The Associations of Job Stress and Organizational Identification with Job Satisfaction among Chinese Police Officers: The Mediating Role of Psychological Capital. Int. J. Environ. Res. Public Health 2015, 12, 15088-15099. [CrossRef] [PubMed]

45. Lin, C.C.; Peng, T.K. From organizational citizenship behaviour to team performance: The mediation of group cohesion and collective efficacy. Manag. Organ. Rev. 2010, 6, 55-75. [CrossRef]

46. Chung, Y.; Yang, J. The mediating effects of organization-based self-esteem for the relationship between workplace ostracism and workplace behaviors. Balt. J. Manag. 2017, 12, 255-270. [CrossRef]

47. Mazzetti, G.; Guglielmi, D.; Chiesa, R.; Mariani, M.G. Happy employees in a resourceful workplace: Just a direct relationship? A study on the mediational role of psychological capital. Career Dev. Int. 2016, 21, 682-696. [CrossRef]

48. Luthans, F.; Avolio, B.J.; Avey, J.B.; Norman, S.M. Positive psychological capital: Measurement and relationship with performance and satisfaction. Pers. Psychol. 2007, 60, 541-572. [CrossRef]

49. Coutu, D. How resilience works. Harv. Bus. Rev. 2002, 80, 46-55. [PubMed]

50. Luu, T.T. Discretionary HR practices and proactive work behaviour: The mediation role of affective commitment and the moderation roles of PSM and abusive supervision. Public Manag. Rev. 2018, 20, 789-823. [CrossRef]

51. Luu, T.T. Service-oriented high-performance work systems and service-oriented behaviours in public organizations: The mediating role of work engagement. Public Manag. Rev. 2019, 21, 789-816. [CrossRef]

52. Pierce, J.L.; Rubenfeld, S.A.; Morgan, S. Employee ownership: A conceptual model of process and effects. Acad. Manag. Rev. 1991, 16, 121-144. [CrossRef]

53. Korsgaard, M.A.; Meglino, B.M.; Lester, S.W.; Jeong, S.S. Paying you back or paying me forward: Understanding rewarded and unrewarded organizational citizenship behavior. J. Appl. Psychol. 2010, 95, 277-290. [CrossRef]

54. Avey, J.B.; Luthans, F.; Youssef, C.M. The additive value of positive psychological capital in predicting work attitudes and behaviors. J. Manag. 2010, 36, 430-452. [CrossRef] 
55. Abbas, M.; Raja, U.; Darr, W.; Bouckenooghe, D. Combined effects of perceived politics and psychological capital on job satisfaction, turnover intentions, and performance. J. Manag. 2014, 40, 1813-1830. [CrossRef]

56. Heled, E.; Somech, A.; Waters, L. Psychological capital as a team phenomenon: Mediating the relationship between learning climate and outcomes at the individual and team levels. J. Posit. Psychol. 2016, 11, 303-314. [CrossRef]

57. Lee, J.; Seo, Y.; Jeung, W.; Kim, J. How ambidextrous organizational culture affects job performance: A multilevel study of the mediating effect of psychological capital. J. Manag. Organ. 2019, 25, 860-875. [CrossRef]

58. Luthans, F.; Youssef, C.M. Human, social, and now positive psychological capital management: Investing in people for competitive advantage. Organ. Dyn. 2004, 33, 143-160. [CrossRef]

59. Goldsmith, A.H.; Veum, J.R.; Darity, W., Jr. The impact of psychological and human capital on wages. Econ. Inq. 1997, 35, 815-829. [CrossRef]

60. Siu, O.L. Psychological Capital, Work Well-Being, and Work-Life Balance Among Chinese Employees. J. Pers. Psychol. 2013, 12, 170-181. [CrossRef]

61. Walumbwa, F.O.; Peterson, S.J.; Avolio, B.J.; Hartnell, C.A. An investigation of the relationships among leader and follower psychological capital, service climate, and job performance. Pers. Psychol. 2010, 63, 937-963. [CrossRef]

62. Newman, A.; Ucbasaran, D.; Zhu, F.; Hirst, G. Psychological capital: A review and synthesis. J. Organ. Behav. 2014, 35, 120-138. [CrossRef]

63. Beggan, J.K. On the social nature of nonsocial perceptions. The mere ownership effect. J. Personal. Soc. Psychol. 1992, 62, 229-237. [CrossRef]

64. Lazauskaite-Zabielske, J.; Urbanaviciute, I.; Balsiene, R. From psychosocial working environment to good performance: The role of work engagement. Balt. J. Manag. 2018, 13, 236-249. [CrossRef]

65. Coutts, L.M.; Schneider, F.W. Police officer performance appraisal systems: How good are they? Polic. Int. J. Police Strateg. Manag. 2004, 27, 67-81. [CrossRef]

66. Martins, L.B.; Zerbini, T.; Medina, F.J. Impact of Online Training on Behavioral Transfer and Job Performance in a Large Organization. J. Work Organ. Psychol. 2019, 35, 27-37. [CrossRef]

67. Rehman, S.U.; Shahzad, M.; Farooq, M.S.; Javaid, M.U. Impact of leadership behavior of a project manager on his/her subordinate's job-attitudes and job-outcomes. Asia Pac. Manag. Rev. 2020, 25, 38-47. [CrossRef]

68. King, E.; Haar, J.M. Mindfulness and job performance: A study of Australian leaders. Asia Pac. J. Hum. Resour. 2017, 55, 298-319. [CrossRef]

69. Khorakian, A.; Sharifirad, M.S. Integrating Implicit Leadership Theories, Leader-Member Exchange, Self-Efficacy, and Attachment Theory to Predict Job Performance. Psychol. Rep. 2018, 122, 1117-1144. [CrossRef]

70. Hackman, J.R.; Oldham, G.R. Development of the Job Diagnostic Survey. J. Appl. Psychol. 1975, 60, 159-170. [CrossRef]

71. Vela, J.C.; Lerma, E.; Whittenberg, J.F.; Hinojosa, Y.; Rodriguez, K. The Role of Positive Psychology, Cultural, and Family Factors in Latina/o College Students' Vocational Outcome Expectations. J. Employ. Couns. 2019, 56, 164-179. [CrossRef]

72. O'Driscoll, M.P.; Pierce, J.L.; Coghlan, A.M. The psychology of ownership: Work environment structure organizational commitment, and citizenship behaviors. Group Organ. Manag. 2006, 31, 388-416. [CrossRef]

73. Md-Sidin, S.; Sambasivan, M.; Muniandy, N. Impact of Psychological Ownership on the Performance of Business School Lecturers. J. Educ. Bus. 2010, 85, 50-56. [CrossRef]

74. Fredrickson, B.L. The role of positive emotions in positive psychology: The broaden-and-build theory of positive emotions. Am. Psychol. 2001, 56, 218-226. [CrossRef]

75. Shim, D.C.; Rohrbaugh, J. An explanation of differences between government offices in employees' organizational citizenship behavior. Public Manag. Rev. 2014, 16, 807-829. [CrossRef]

76. Luthans, F.; Avolio, B.J.; Walumbwa, F.O.; Li, W. The psychological capital of Chinese workers: Exploring the relationship with performance. Manag. Organ. Rev. 2005, 1, 249-271. [CrossRef]

77. Gooty, J.; Gavin, M.; Johnson, P.D.; Frazier, M.L.; Snow, D.B. In the eyes of the beholder: Transformational leadership, positive psychological capital, and performance. J. Lead. Org. Stud. 2009, 15, 353-367. [CrossRef]

78. Avey, J.B.; Reichard, R.J.; Luthans, F.; Mhatre, K.H. Meta-analysis of the impact of positive psychological capital on employee attitudes, behaviors, and performance. Hum. Resour. Dev. Q. 2011, 22, 127-152. [CrossRef]

79. Bandura, A. Perceived self-efficacy in cognitive development and functioning. Educ. Psychol. 1993, 28, 117-148. [CrossRef]

80. Chen, I.S. Examining the linkage between creative self-efficacy and work engagement. Balt. J. Manag. 2016, 11, 516-534. [CrossRef]

81. Bargsted, M.; Ramírez-Vielma, R.; Yeves, J. Professional Self-efficacy and Job Satisfaction: The Mediator Role of Work Design. J. Work Organ. Psychol. 2019, 35, 157-163. [CrossRef]

82. Konovsky, M.A.; Pugh, S.D. Citizenship Behavior and Social Exchange. AMJ 1994, 37, 656-669.

83. Lemoine, G.J.; Parsons, C.K.; Kansara, S. Above and beyond, again and again: Self-regulation in the aftermath of organizational citizenship behaviours. J. Appl. Psychol. 2015, 100, 40-55. [CrossRef]

84. Lin, S.Y.; Chen, H.C.; Chen, I.H. When perceived welfare practices leads to organizational citizenship behavior. Asia Pac. Manag. Rev. 2016, 21, 204-212. [CrossRef]

85. Organ, D.W. Organizational citizenship behavior: It's construct cleanup time. Hum. Perform. 1997, 10, 85-97. [CrossRef]

86. Choi, B.K.; Moon, H. Prosocial motive and helping behaviour: Examining helping efficacy and instrumentality. J. Manag. Psychol. 2016, 31, 359-374. [CrossRef] 
87. Williams, L.J.; Anderson, S.E. Job satisfaction and organizational commitment as predictors of organizational citizenship and in-role behaviors. J. Manag. 1991, 17, 601-617. [CrossRef]

88. Wendler, K.; Liu, J.; Zettler, I. Honesty-Humility Interacts With Context Perception in Predicting Task Performance and Organizational Citizenship Behavior. J. Pers. Psychol. 2018, 17, 161-171. [CrossRef]

89. Doyle, K.; Goffin, R.; Woycheshin, D. Peer-Rated Organizational Citizenship Behavior Does Familiarity Improve Rating Quality? J. Pers. Psychol. 2019, 18, 129-137.

90. Podsakoff, P.M.; MacKenzie, S.B.; Paine, J.B.; Bachrach, D.G. Organizational citizenship behaviors: A critical review of the theoretical and empirical literature and suggestions for future research. J. Manag. 2000, 26, 513-563. [CrossRef]

91. Vande Walle, J.G.; Donckerwolcke, R.A.M.G.; van Isselt, J.W.; Joles, J.A.; Koomans, H.A.; Derkx, F.H.M. Volume regulation in children with early relapse of minimal-change nephrosis with or without hypovolaemic symptoms. Lancet 1995, 346, 148-152. [CrossRef]

92. Kyei-Poku, I. The benefits of belongingness and interactional fairness to interpersonal citizenship behavior. Leadersh. Organ. Dev. J. 2014, 35, 691-709. [CrossRef]

93. Talukder, A.K.M.M.H. Supervisor Support and Organizational Commitment: The Role of Work-Family Conflict, Job Satisfaction, and Work-Life Balance. J. Employ. Couns. 2019, 56, 98-116. [CrossRef]

94. Gupta, M.; Shaheen, M.; Reddy, P.K. Impact of psychological capital on organizational citizenship behaviour: Mediation by work engagement. J. Manag. Dev. 2017, 36, 973-983. [CrossRef]

95. De Clercq, D.; Rahman, Z.; Haq, I.U. Explaining helping behavior in the workplace: The interactive effect of family-to-work conflict and Islamic work ethic. J. Bus. Ethics 2019, 155, 1167-1177. [CrossRef]

96. Antunes, A.C.; Caetano, A.; Cunha, M.P. Reliability and Construct Validity of the Portuguese Version of the Psychological Capital Questionnaire. Psychol. Rep. 2017, 120, 520-536. [CrossRef] [PubMed]

97. Peterson, S.J.; Luthans, F. The impact of financial and nonfinancial incentives on business-unit outcomes over time. J. Appl. Psychol. 2006, 91, 156-165. [CrossRef]

98. Medlin, B.; Green, K., Jr.; Gaither, Q. Developing optimism to improve performance: A pilot study in the education sector. Acad. Organ. Cult. Commun. Confl. Proc. 2010, 15, 38-42.

99. Brislin, R.W. Cross-Cultural Research Methods. In Environment and Culture. Human Behavior and Environment (Advances in Theory and Research); Altman, I., Rapoport, A., Wohlwill, J.F., Eds.; Springer: Boston, MA, USA, 1980; Volume 4.

100. Kline, R. Principles and Practice of Structural Equation Modeling, 4th ed.; The Guilford Press: New York, NY, USA, 2014.

101. Schermerhorn, J.R., Jr.; Hunt, J.G.; Osborn, R.N. Organizational Behavior, 7th ed.; John Wiley \& Sons: New York, NY, USA, 2000.

102. Farh, J.L.; Cheng, B.S. Modesty bias in self-rating in Taiwan: Impact of item wording, modesty value, and self-esteem. Chin. J. Psychol. 1997, 39, 103-118.

103. Fornell, M.; Larcker, D.F. Structural Equation Models with Unobservable Variables and Measurement Error. J. Mark. Res. 1981, $18,39-51$. [CrossRef]

104. Hair, J.F.; Black, W.C.; Babin, B.J.; Anderson, R.E.; Tatham, R.L. Multivariate Data Analysis, 6th ed.; Prentice-Hall: Upper Saddle River, NJ, USA, 2006.

105. Browne, M.W.; Cudeck, R. Alternative ways of assessing model fit. In Testing Structural Equation Models; Bollen, K.A., Long, J.S., Eds.; Sage: Newbury Park, CA, USA, 1993; pp. 136-162.

106. Hu, L.T.; Bentler, P.M. Evaluating model fit. In Structural Equation Modeling: Concepts, Issues, and Applications; Hoyle, R.H., Ed.; Sage Publications, Inc.: Thousand Oaks, CA, USA, 1995; pp. 76-99.

107. Dutton, J.E.; Roberts, L.M.; Bednar, J. Pathways for positive identity construction at work: Four types of positive identity and the building of social resources. Acad. Manag. Rev. 2010, 35, 265-293.

108. Wang, L.; Law, K.S.; Zhang, M.J.; Li, Y.N.; Liang, Y. It's mine! Psychological ownership of one's job explains positive and negative workplace outcomes of job engagement. J. Appl. Psychol. 2019, 104, 229-246. [CrossRef]

109. Chu, L.C. Mediating positive moods: The impact of experiencing compassion at work. J. Nurs. Manag. 2014, 24, 59-69. [CrossRef] [PubMed]

110. Moon, T.W.; Hur, W.M.; Ko, S.H.; Kim, J.W.; Yoo, D.K. Positive work-related identity as a mediator of the relationship between compassion at work and employee outcomes. Hum. Factor. Erg. Man. 2016, 26, 84-94. [CrossRef]

111. Pohl, S.; Vonthron, A.; Closon, C. Human resources practices as predictors of organizational citizenship behaviour: The role of job breadth and organizational support. J. Manag. Organ. 2019, 25, 224-238. [CrossRef]

112. Kramar, R. Beyond strategic human resource management: Is sustainable human resource management the next approach? Int. J. Hum. Resour. Manag. 2014, 25, 1069-1089. [CrossRef]

113. Blustein, D.L.; Kenny, M.E.; Fabio, A.D.; Guichard, J. Expanding the Impact of the Psychology of Working: Engaging Psychology in the Struggle for Decent Work and Human Rights. J. Career Assess. 2019, 27, 3-28. [CrossRef] 